\title{
Legitimising the Present through the Past: Some Observations on the Use of the Past in Territorial Disputes
}

\author{
Manolis E. Pagkalos \\ (University of Leicester)
}

\begin{abstract}
One of the most common expedients for preventing conflicts, especially from the Hellenistic period onwards, was the recourse to interstate arbitrations. The phenomenon was not restricted only to the great powers of the day; smaller states would often resort to the process in order to pursue their own interests through less demanding, in militaristic and financial, terms. From the Archaic period to the Hellenistic and Roman periods, and from prominent poleis like Athens and Sparta to smaller ones, the past was prominently used in the context of interstate arbitrations to legitimise claims or actual possession of territories. A favourable verdict would offer direct and tangible benefits for the winning side. However, much like its use in the political discourse, the past played a central role in the arbitrating courts. More so, a positive verdict was not only the outcome of compelling argumentation, but it was supported by historical evidence both in the form of mythical and/or historical accounts and of historical memories. Thus, alongside the many practical benefits, there are other, at least equally, important advantages; namely, the effective alteration of the modes of self-representation and the ability to mould civic identities. This paper will discuss various instances of the use of the past within the interstate arbitration corpus and will examine its central position in yet another aspect of the political life of Ancient Greece, especially from the Hellenistic period onwards.
\end{abstract}

\section{Keywords}

interstate arbitrations; use of the past; history; international law; rhetoric; Aristotle; pisteis; politics

This article is the result of a research paper presented at the Laetae Segetes V Conference (Brno, November 13th-16th). I am grateful to Professor Graham Shipley and my colleague Stefanos Apostolou for their insightful comments and suggestions. All translations provided are my own, unless otherwise indicated. When no era is specified, the dates should be taken as BC. 
In the introduction of his work on the philosophy of history, Walsh defines history as the "intelligent reconstruction of the past" (Walsh 1960: p. 32). One can argue against this definition (cf. Carr 2015) and, in reality, the definition of history is far more complex as history is both a term and a concept. It could be better understood as the linguistic and cultural index of a variety of ways of understanding social temporality (Liakos 2007: p. 30). However, the intention of this paper is not to explore "what history is", but to investigate the potency of history and, consecutively, what the past can offer in any society. Walsh has captured this brilliantly in his definition of history: the potentiality of the use of the past; the possibility to "intelligently" manipulate the past so as to reconstruct an intelligent version of it.

The political potency of the past and its use has been understood from quite early, and almost all political rhetoric depended on the past as a legitimation device (Fentress \& Wickham 1992: p. 128; Assmann 2011: pp. 129-131). Thus, the past acquired, from early on, a central position in the political discourse both inside and outside the community. Under this perspective, the use of the past should be described as "intentional", in effect creating what Gehrke terms as 'intentional history' (Gehrke 2001: p. 298): "the history of a group as seen and understood by it, a sum of traditions, which can be forged, be fictitious or just believed by a group, which holds them as real". ${ }^{1}$ Similarly to Walsh, Gehrke vividly describes the opportunities that the past can offer as the possibility of forged or fictitious traditions are centrally located in his concept. ${ }^{2}$

Delving further into ancient history, there are many instances that can highlight the manipulation of the past, the realisation of its power and the construction of new narrations. However, this paper will focus on a specific topic of the ancient world, one that it is political to its very core, while it exceeds its limits as it touches topics of identity, representation and legality - the institution of interstate arbitrations. An overview on the use of the past in the claims of contesting poleis will demonstrate the particular dynamics of its use within one of the first instances of 'international law' in the Greek world (Ager 1996: pp. 30-31; Chaniotis 2004: pp. 186-187; Magnetto 2016). Although the institution of interstate arbitrations has links to the intra-polis public and private arbitrations, ${ }^{3}$ it was a quasi-legal process without any professional standardisation - at least at the time. However, its links to the concept of justice were very strong (Ager 1996: p. 33). The verdict, although mostly reached upon through impartiality and intrapolitical judicial customs, was not only the outcome of a persuasive argument. Just as within the public courts of a polis, evidence should be presented in support of any claim or defence: public

1 On the concept of "intentional history" see also, Foxhall et al. (2010); Gehrke (2014).

2 The topic of fictitious traditions has been explored in depth by many scholars, yet Eric Hobsbawm and Terence Rangers's work on the Invention of tradition is of paramount importance. For the ancient world, the works of Luraghi $(2002 ; 2008 ; 2009)$ and Flower (2002) for Messenian and Spartan uses of the past offer excellent examples of the many applications of the topic in antiquity.

3 On the topic of Ancient Greek arbitration in the private and public sphere of the polis, see Roebuck (2001). 
documents, inscriptions and verbal witnesses. Nevertheless, in the context of interstate arbitrations, it is often that these can also take the forms of historical evidence - be it mythical or historical accounts and memories (Curty 1989: pp. 29-31; Ager 1996: pp. 15-17; Shipley 2013). The use of such evidence - in effect, the use of the past - next to the possible practical benefit, a positive verdict, offers other, equally important benefits for a polis. These include the possibility to alter the reality and the modes of representation of a polis' past and, therefore, molding and solidifying civic identity.

II

The institution of interstate arbitration (K@írı) belongs to a broader range of conflict resolution mechanisms in international relations. The disputants, most often two poleis or other political entities, were to submit legal arguments and then accept the impartial judgement of a neutral third party. In contrast to other third-party interventions like mediation and good offices, a successful arbitration did not leave room for compromise - the judgment was theoretically binding, even if the final verdict may seem unacceptable by partakers (Ager 1996: p. xiv). And it is in theory binding, as the arbitrator should have both the will and the military or economic power to force or support a decision when needed. ${ }^{4}$

In the ancient world, the majority of interstate arbitrations concerned territorial disputes, thus, although they were a diplomatic protocol adhering to legal procedure, they may be as well very political in nature. First, this is because the initiation of arbitration was a political act enacted by one city and required both a response (defence) by the second party and a suitable and mutually agreeable arbitrator. Secondly, the benefits of acquiring or protecting a territory had political and financial reverberations for the disputants. Thirdly, due to the fluid nature of politics per se, it may be that the circumstances which led to an arbitration may change. This is mostly true for cases of obligatory arbitrations, where the arbitrations were enforced due to the existence of an arbitration clause in a previous pact (Ager 1996: p. 9). Even when such a previous pact did not exist, and the arbitration was a result of a free agreement between the parties (compromissory arbitration), the political overtone is visible on the many examples of repeated cases. ${ }^{5}$ The interested parties would appeal to any new, potential arbitrator with hopes of different outcome (Magnetto 2016). Lastly, the institution of interstate arbitration as a diplomatic tool to avoid direct conflict was very appealing to smaller states that were often incapable of pursuing their own interests through other means. Contrariwise, more powerful states or individuals would most likely avoid such judicial

4 The widespread use of interstate arbitration, especially from the Hellenistic period onwards, suggests that it was a useful and worthy tool despite the average success rate, see Ager (1996: p. 33).

5 Some examples of repeated cases include the territorial disputes between Samos and Priene, Sparta and Messene or Megalopolis. 
processes as they could impede their goals which could be achieved in far more direct ways (Ager 1996: pp. 3-4). ${ }^{6}$

As discussed previously, interstate arbitrations, in effect a legal procedure, share many similarities with public and private arbitrations (Ager 1996: p. 33). They abide by a fairly formal process in which the judge or arbitrator held power to render a judgement, with binding force for both parties. The arbitrator - be it a body of judges, a court or an individual - would listen to the legal arguments of both sides, presented by advocates who would plead their poleis' cases separately. Once again, similarly to the law courts, in order for an argument to be strong, it should adhere to certain rules. Aristotle, in his Rhetoric $(1.2 ; 2.1)$, describes three modes of persuasion that classify the speaker's appeal to his audience, the pylons of forensic art: ethos, pathos, and logos. A speaker, in order to be persuasive, has to appear credible (ethos), to emotionally influence the audience (pathos), and to build a logical or plausible argument (logos), each pistis should be adapted according to the audience and the case. Oratory, a techne so connected with politics, had a profound role to play in the arbitrational courts. Each party and its representative(s) would follow these directives in order to maximise their efficacy. Moreover, the connection is clearer if we are to incorporate the fourth concept of rhetorical devices, that of kairos; ${ }^{7}$ in other words, the proper or opportune time for the poleis to initiate an arbitration. In the case of repeated arbitrations, this timing is closely connected to the belief that changes in the international hierarchy could result in different and potentially positive results.

In many cases, it is hard to approach the question of the ethos of the advocates, yet it seems that men could acquire fame and expertise over time, which resulted in honouring decrees. ${ }^{8}$ It is also hard to identify the possible emotional influence (pathos) that an advocate could incite to the court. In any case, appeals to emotion(s) were as important as valid arguments, as it is true in any court context (Ager 1996: p. 15). In the context of this article, I would like to focus on the logical arguments (logos) that a polis, by the voice of their representatives, would make in support or defence of any claim. In order to build a logical and plausible line of argument, the opposing parties should provide evidence of support - to follow Aristotle's definition, the inartistic proof (1.15). As al-

6 Another reason that powerful poleis or individuals would avoid arbitration was the potential lack of a suitable arbitrator, as in the case of Athens and Sparta on the outbreak of the Peloponnesian War, in 431 (Ager 1996: p. 20). Even when one was (readily) available, both in terms of prestige and power, submission to the process required its recognition as such and could potentially lead to subjection (through possible enforcement). Both instances represent a very difficult reality, one that powerful parties would try to avoid nonetheless.

7 For the concept of kairos in both ancient and modern oratory as well as in the works of Aristotle, see Kinneavy \& Eskin (2000); Kinneavy (2002).

8 In the Senate arbitration of the land dispute between Abdera and Kotys (Syll. $\left.{ }^{3} 656\right)$ the advocates of Abdera are honoured by the city. However, they were citizens of Teos, which was asked to intervene due to its connections with Rome and they were honoured despite their unsuccessful attempt (Ager 1996: no 169). In a similar case, the Athenian Apollodoros is honoured by the Delphians for acting as their advocate in the dispute between Delphoi and Amphissa (Syll. $\left.{ }^{3} 615\right)$. A different case can be seen in the arbitration between Zarax and Epidauros Limera (SEG XI.894), where the two advocates and brothers, Angeles and Theodoros, are honoured for their two consecutive successes. However, the decree clearly demonstrates the dangers in case of an unsuccessful outcome, Ager (1996: no 80). 
ready discussed, in the context of interstate arbitrations it is not uncommon to find documentary evidence in support of a case. Still, how such evidence could be used to promote a case? What was the range of possibilities that they offered to any community?

\section{III}

From the Archaic period, interstate arbitrations were frequently used to settle conflicts between poleis in the grounds of territorial disputes (Tod 1913; Piccirilli 1973; Giovannini 2007: pp. 177-184). Their applied context was that of interstate relations, both standing within customary law and acting as a diplomatic protocol. From early on, any ruling working in this general, although by far not conventionalised, context was based on argumentative and juridical processes. To prove a claim of ownership, most commonly, the parties had either to build a case of original possession, fixing the ownership of the disputed land at a point lost in time - at the very beginning ( $\dot{\varepsilon} \xi \dot{\alpha} \varrho \chi \tilde{\eta} \varsigma)$ - or to establish a continuous and unbroken line of possession. ${ }^{9}$ It was both logical and useful for the outcome to demonstrate hereditary ownership, true or constructed. If the city could convincingly argue that the land was given to them by their ancestors, they would have offered a very strong case in their defence. The principle of original ownership to prove rights over land has deep roots in Greek history (Chaniotis 2004). This kind of supporting evidence can be seen in one arbitration example from the Archaic period.

The Athenians and the Megarians had been involved in a long dispute over the island of Salamis. Eventually, the dispute was submitted to Spartan arbitration (Plut. Sol. 10; Arist. Rh. 1.15.13; Piccirilli 1973: no 10). Among the evidence that the Athenian envoys brought forth to prove their ancestral rights over the island were both archaeological finds and historical evidence (Higbie 1997; Chaniotis 2004: p. 200). According to the account, Solon described the differences between the two poleis' burial customs. Moreover, he supported the Athenian claim citing as evidence Homer and the Homeric Catalogue of Ships (Hom. Il. 2.258 $)^{10}$ making a connection to Ajax and his sons, who were naturalised Athenian citizens. ${ }^{11}$ Moreover, Solon not only quoted lines of the Iliad, after presumably altering the original, ${ }^{12}$ but he connected the epic past to contemporary reality by highlighting the

9 There are other ways to claim rights over the land as it is explicitly demonstrated in the arbitration of Magnesia on Maiandros between the Cretan poleis Hierapytna and Itanos (Syll. $\left.{ }^{3} 685\right)$, see Ager (1996: no 158); Chaniotis (2004).

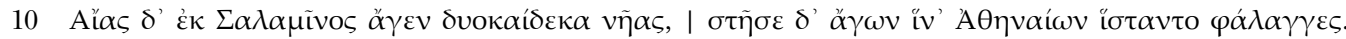
[trans. Ajax from Salamis brought twelve ships and stationed them where the battalions of the Athenians were positioned.]

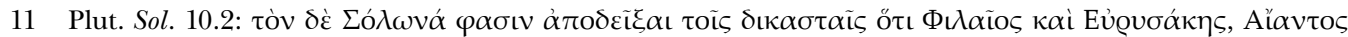

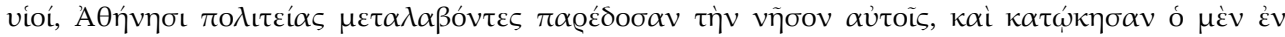

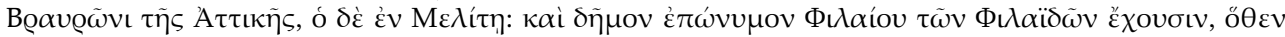

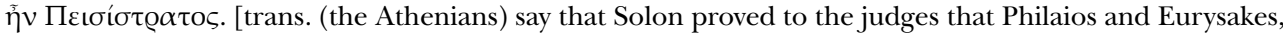
the sons of Ajax, became citizens of Athens, delivered their island to them, and took up their residence, one at Brauron of Attica, and the other at Melite; and they have a deme named after Philaios, namely (the deme of) Philaidai, to which Peisistratos belonged.]

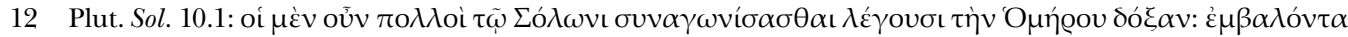


connection of Philaios, Ajax's son, with Brauron. ${ }^{13}$ Except for the obvious use of such evidence for political purposes, what is striking is the alleged use of epic poetry as historical evidence. Nevertheless, this should not strike us as something peculiar.

Interestingly, Aristotle (Rh. 1.15) describes the inartistic proofs used in the court, the evidence that is not created by the speaker; these are five: laws, witnesses, contracts, torture, and oaths. ${ }^{14}$ Among them, at least two overlap with the theoretical background provided by the Magnesian arbitrators in their statement concerning the land dispute between Itanos and Hierapytna $\left(S y l l .{ }^{3} 685\right.$; $\left.11.133-134\right):{ }^{15}$ the laws and contracts can be paralleled in the rights based on original possession and hereditary ownership, purchase, conquest or benefaction. In the Rhetoric (1.15), Aristotle goes on and analyses the term 'witnesses' and states that there are two kinds: old and recent. The category of 'old' includes those "whose judgement was known to all" $(R h .1 .15 .13)^{16}$ - "namely, the poets and men of repute'. The margin for interpretation is evidently quite wide, and although sources like Homer and Hesiod were believed as trustworthy references, the distinction between myth (invented past) and historical fact is difficult (Gehrke 2001: p. 299; Assmann 2011: pp. 247-255). Even Plutarch in his account is quick to add that the Athenians dismissed the accusation for forgery as "nonsense" ( $\varphi \lambda v \alpha \varrho i ́ \alpha v)$ and provides further historical connections to the deme, namely Peisistratos. One should indeed wonder whether such proof of evidence is truly inartistic or not.

Homer was cited in support of the Athenian claim of ownership since the very beginning; albeit Plutarch is the detailed source of the account, both he and Aristotle make it clear that the Spartan arbitrators decided in favour of Athens. It seems that the rhetorical skills of Solon, along with the use of epic poetry and tangible evidence, won the day for the Athenians. By citing Homer, the Athenians were connecting the ownership of Salamis with a distant past, acknowledged by both parties but still not located in a very precise moment. This is because, in principle, any claim of original possession from the beginning is imprecise. It only becomes precise when is used by a claimant who defines it as a pivotal event that created a new beginning. This convenient moment can be set wherever in the historical timeframe. More importantly, any beginning sets a point before which no other right could be claimed (Chaniotis 2004: pp. 201-202; Magnetto 2016). As with the use of the past for the formation of civic identities, the power of such

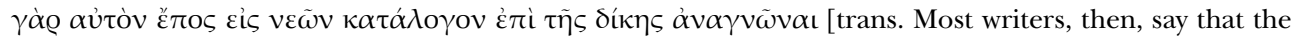
fame of Homer favoured the contention of Solon; for after he himself inserted a verse into the Catalogue of Ships, he read it at the trial]

13 For a discussion on the topic of Solon's interpolation and its reception, see Patterson (2010: pp. 70-74, 166-169).

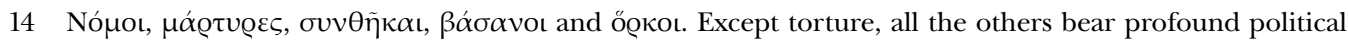
ramifications and connections next to their juridical applications.

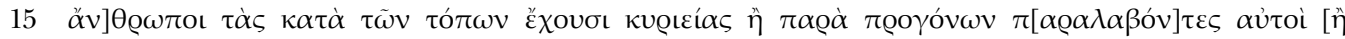

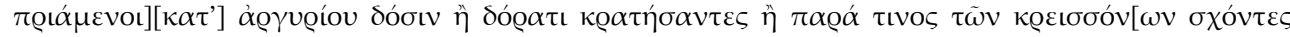
[trans. men have proprietary rights over land either because they have received themselves the land from their ancestors, or because they have bought it for money, or because they won it by spear, or because they have received it from someone of the powerful].

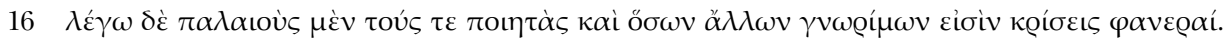


notions and its understanding was inescapable by any political authority (Gehrke 2001: p. 298; Clarke 2008: pp. 313-317). ${ }^{17}$

Of course, this is not the only case where such 'applied' evidence was used in arbitrated dispute over territory. In the aforementioned dispute between the Cretan poleis of Itanos and Hierapytna (c. 140-111; Syll. ${ }^{3} 685$ ) by Magnesia-on-the-Maiandros, the liti-

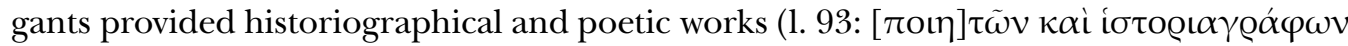

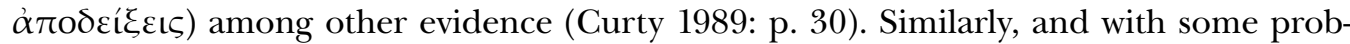
ability due to the lacuna of the inscription, in the dispute between Mytilene and Pitane submitted to Pergamon (c. 150-133; OGIS 335) the two poleis used historiographical evidence $^{18}$ (Curty 1989: p. 30; Ager 1996: no 146).

However, we can see in detail the potential of the use of historical evidence in a much later example. According to Tacitus (Ann. 4.43.1-3) in the arbitration of Emperor Tiberius and the Roman Senate (AD 25) between Messene and Sparta over the temple of Artemis Limnatis in the region of Dentheliatis, both the Messenians and the Spartans offered evidence of historical authors (memoria annalium) and poets (carminibus vatum) next to epigraphical evidence (Ager, 1996: no 50). ${ }^{19}$ It is difficult to evaluate the validity of the presented evidence, but the emperor ruled in favour of the Messenians. The verdict followed a long tradition of positive rulings for the Messenians..$^{20}$ What is of interest here is the extent of the approach and use of the mythical past in order to prove ancestral possession of the region. The Spartans supported their claim on the land by invoking the time when they had built the temple of Artemis Limnatis. In response, the Messenians went further back into the past, reaching out to the most prominent myth of Peloponnesos: the return of the Herakleidai. For the Messenians, this 'fact' was inscribed on stone and bronze ${ }^{21}$ - even if the existence of such evidence is in itself suspicious due to its strong political overtones. According to Tacitus, next to the inscribed evidence, they also pointed to the abundance of historical and poetic testimonies. ${ }^{22}$ The use of the myth for the political authority and identity of different poleis in Peloponnesos is well attested (Luraghi 2008: pp. 46-61; Stafford 2012: pp. 137-142). However, here it is used as 'tangible' evidence in the context of a judicial procedure, and on these grounds, a successful one. This case is also interesting for another reason; it demonstrates the complexity of the use of the past. It is possible that Tiberius' decision was influenced by an interplay of memory and the use of the past within the Roman Empire, as the only arbitrations favourable to Sparta were those of Caesar and Marcus Antonius. It may be

17 For its uses for the formation of identity through foundation myths during the colonisation, see Mac Sweeney $(2013 ; 2015)$.

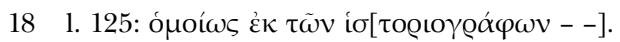

19 Luraghi (2008: pp. 16-27) offers a detailed discussion on the political and cultural ramifications.

20 In chronological order, arbitrations concerning the same region have been submitted to King Antigonos III Doson (c. 222); the general Lucius Mummius Achaicus (146/5); the people of Miletos (c. 138; IvO 52); Caesar; Marcus Antonius; and the praetor of Achaia, Atidius Geminus (c. AD 25). See Luraghi (2008: pp. $16-27)$.

21 monimentaque eius rei sculpta saxis et aere prisco manere.

22 quod si vatum, annalium ad testimonia vocentur, pluris sibi ac locupletiores esse. 
that the emperor wanted to solidify his own links to Augustus and the ideology of empire, which was cultivated by the opposition between the old and declining Republic and its civil wars and the new, powerful state (cf. Gibson 2014: pp. 138-139).

We can further explore the dynamics of a malleable past in the two arbitrations between Samos and Priene. In the letter of King Lysimakhos to the Samians (c. 283/2; OGIS 131; Ager 1996: no. 26) the representatives of the two poleis presented as evidence

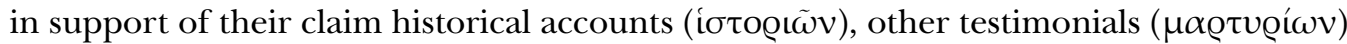

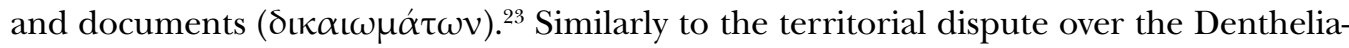
tis, where the Messenian advocates cited the legend of the Herakleidai to prove original ownership of the region, the Prieneans tried to prove that the disputed land of Batinetis originally belonged to them. Their argument was based on events that took place in the distant past, in the wake of the Melian War (Vitr. 4.1.4-5; cf. Val. Max. 1.5 ext.). ${ }^{24}$ Although the Prienean envoys recited specific historical events, like the invasion of Ionia by the Kimmerian king Lygdamis (11. 14-15) or the Six-Years' Truce (1. 13), their argument comes to a sudden halt after the victory of the Samians over the Prieneans, when Bias was sent to conclude a peace (11. 21-24). ${ }^{25}$ The very omission of three hundred years of history is suspicious. What is more striking is the fact that historical narration of the Prienean account ends with the invocation of Bias, an authoritative figure, well known for his probity (Welles 1934: pp. 49-50; Bagnall \& Derow 2004: p. 27). It seems like an attempt to emotionally influence the outcome, something both possible and acceptable in the context of rhetorical devices. Additionally, it is not the only instance of an emotional approach implemented by the Prieneans. Other evidence points towards an intentional choice of Lysimakhos as the arbitrator. Priene and the king had very good relations, evident in an honouring decree (IPriene 14); the Prieneans had established a cult of Lysimakhos and erected a bronze statue of the king in their agora (Lund 1992: pp. 164-165; Magnetto 1997). ${ }^{26}$ It is plausible that the Prieneans approached Lysimakhos

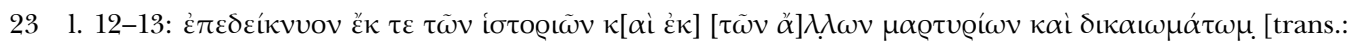
(the envoys from Priene) presented by means of the histories and other testimonials and documents].

24 On the so-called Melian War, see Shipley (1987: pp. 29-31); Magnetto (2008: pp. 81-92); Mac Sweeney (2013: pp. 178-186).

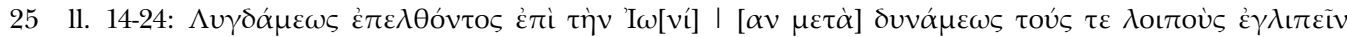

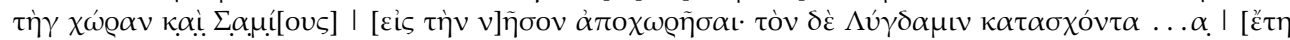

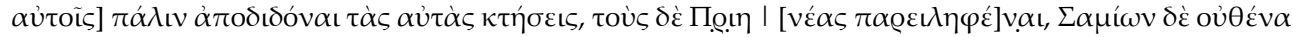

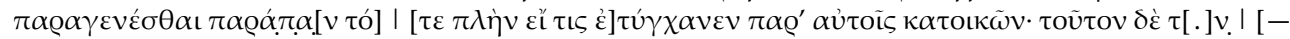

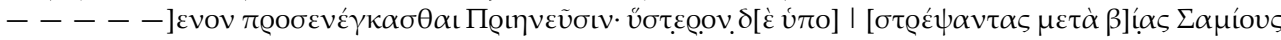

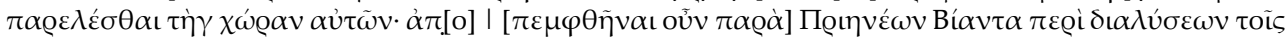

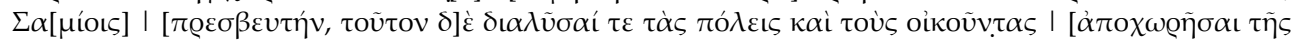

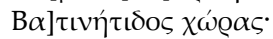

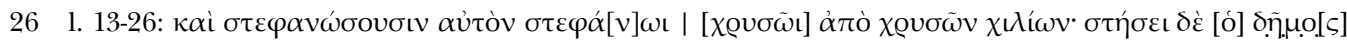

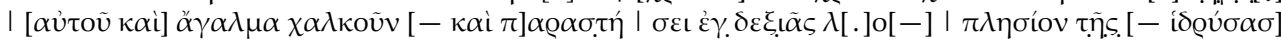

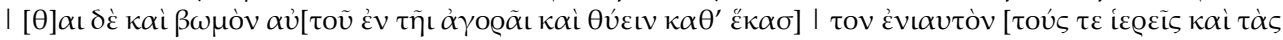

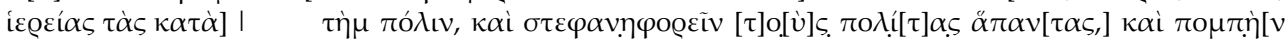

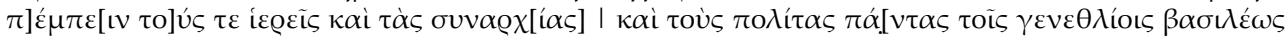

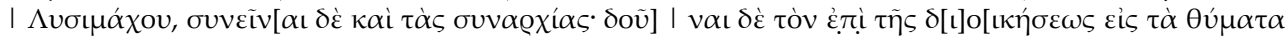

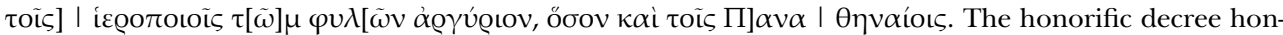
oured Lysimakhos as soter for his intervention in the protection of the city against the attack of the Pedieis 
in light of their relations and with aims to further benefit by it. However, in contrast to the Prieneans' best wishes, Lysimakhos seems to have judged impartially and in favour of the Samians. The Prieneans did not manage to establish a persuasive claim of original ownership. Instead, the Samians' line of argument presumably trod on both grounds of

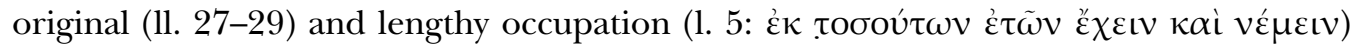
of Batinetis up until the hearing in the court of the king, and challenged successfully the Prienean account.

Arguably, the long tradition of territorial disputes between the two poleis did not end with King Lysimakhos' letter. A later Rhodian arbitration between the parties (c. 196-192; IPriene 37+38; Syll. ${ }^{3}$ 599) cross-checked some of the Samian claims. However, this later arbitration involved with a different area, the fort of Karion and its surrounding chora called Dryoussa, and leaves Batinetis out of the dispute (Ager 1996: no 74). What is interesting in the decree of the Rhodian arbitrators is the way that the Samians attempted to tilt the court in their favour. According to the account, the Samians presented "the

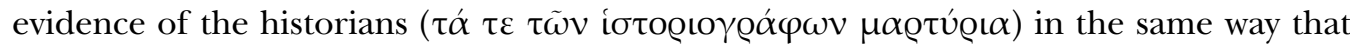
they did in the previous arbitration regarding Batinetis" (1. 101-102). In support of their claim over Karion, the two parties presented the works of several historians as evidence: Maiandrios of Miletos; Ouliades, Olympikhos, Douris, and Euagon of Samos; Kreophylos and Eualkes of Ephesos; and Theopompos of Khios. ${ }^{27}$ The Samians claimed original possession of Karion and Dryoussa since the aftermath of the Melian War, whereas the Prieneans refuted the claim. In support of their claim, the Samians brought forth the evidence from three historians, yet apparently, only the account of Maiandrios of Miletos accounted for such an allocation. Despite already having a positive verdict from King Lysimakhos' arbitration, the Samians went so far as to forge a historical narrative (Chaniotis 2004: p. 193). As the verdict of the Rhodian court demonstrates, the account of Maiandrios was dismissed as spurious ( $\psi \varepsilon v \delta \varepsilon \pi i \gamma \varrho \alpha \varphi \circ \varsigma, 1.123)$. Consecutively, the Samians lost the case, and Karion and its surrounding land were confirmed to belong to the Prieneans.

What information can we extract from this last example? First, this instance provides evidence of the copious preparations of the advocates. They did not only have to study the historical works of several local historians and to locate evidence in support of their case. They also needed to build a convincing reconstruction of the past based on this evidence (Magnetto 2016). This consists the first level of the use of the past. Secondly, we can trace the rigorous assessment of the presented evidence by the Rhodian arbitrators.

and Magnesia. Among the honours, an altar and annual sacrifices were established, as well as a gold crown of 1,000 staters were offered to the king. Moreover, the cult acquired every year the same amount of money offered for the Panathenaia, equating the two celebrations.

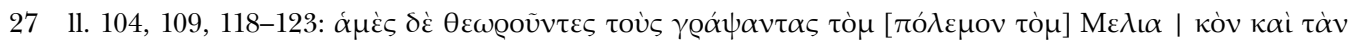

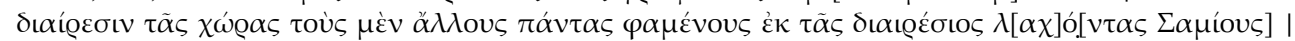

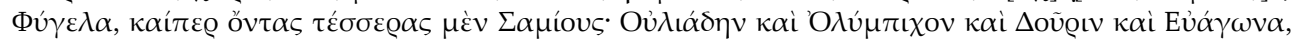

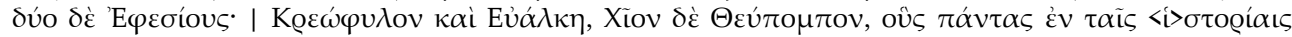

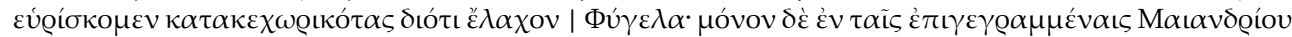

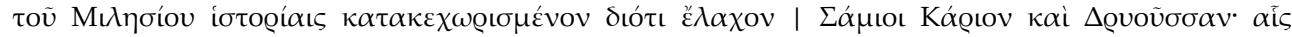

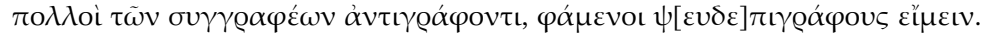


After a thorough examination of the evidence, they singled out the one account that appeared tampered. ${ }^{28}$ Alas, the nature and/or extent of the alteration of Maiandrios' account cannot be traced. It may be that the presented work was a forgery or that part of Maiandrios' historical account had been falsified in favour of the Samians (Curty 1989: pp. 28-29). In any case, the falsification of the account offers an excellent example of the extent and reach of the manipulation of the past by political authorities (Clarke 2008: pp. 314-315). The manipulation is multi-layered; this is the second level, where the evidence (historical accounts) were altered in order to alter the past itself. According to Aristotle, historical testimonies, as documented evidence, were infallible; yet, it seems that they could be equally invented or tampered with.

\section{IV}

In the case of the second arbitration between Samos and Priene, local historians were used as evidence for both parties, and arguably they could provide a level of support to the claims of the defendants or effectively dismiss them. However, what is important here is to highlight the great potential of their use as evidence. Any city could use such historical sources, and as seen from the Rhodian arbitration these may be local histories, as evidence in support of its claim over disputed territory and support claims of possession since a distant past. A dual use of the past has already been identified: a historical narrative was used as proof of evidence of a 'historical' past - and both were prone to alteration and political motivations. In other words, if the past, which is not at all impervious to manipulation, can be used to support territorial claims based on specific narratives of this past, one can see the numerous opportunities for exploitation by any political authorities. Even more so, if we contextualise them within the sphere of oratorical discourse.

The verdict of an arbitration over disputed land was a form of legitimisation both of the validity of the claims of a polis and through it, of its past. The possible alteration of the latter was analogous to the extent that the historical evidence had been tampered with. The new, reconstructed past, or to return to Walsh's definition, the "intelligent reconstruction of the past" was then a legitimate version of the history of that polis. And it could have been further used as evidence within a court, as the two arbitrations between Samos and Priene showcase. The impact on the way in which local history can be changed and articulated is easily perceived. Until now we concerned ourselves with the way in which communities could change a narrative, even a written one, in order to receive direct benefits. Such a renarration of the past has multiple consequences to the knowledge and perception of this

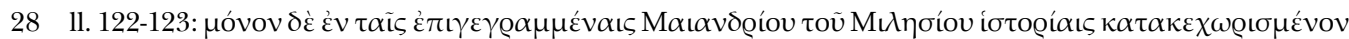

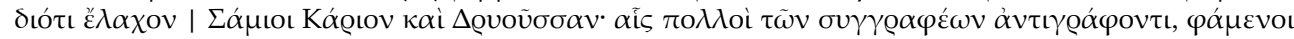

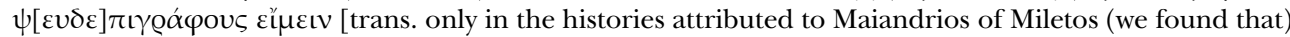
it recorded that the Samians were allotted Karion and Dryoussa; but this is contradicted by the majority of writters, we say that (these histories) are not authentic.] 
past by the community - the (re)formation of its civic identity is only one of them. What about the actual visual proof of an arbitration, or the absence of one?

A successful arbitration was a topos of civic prestige; the verdict would be published on stone and would be on public display in a prominent space, authorised by the community. For example, the Samians displayed the letter of Lysimakhos at the Heraion, whereas the Prieneans displayed the Rhodian arbitrations at the archive wall at the temple of Athena Polias (Sherwin-White 1985: pp. 71-72; Patronos 2002: pp. 146-149). For both poleis, these inscriptions constituted a confirmation of the polis' status and were incorporated into its civic reality and memory, shaping how the two communities perceived their own past, present, and future (Sherwin-White 1985: pp. 86-87). At the same time, they were messages to other poleis, altering the representation and reception of the polis' image externally. The fact that unsuccessful attempts of arbitrations are silently omitted from the archival wall of Priene points towards the way that the community wished its own history to be recorded, while it strengthened unity and cohesion among the citizen body (Ager 1996: p. 18; Magnetto 2009: p. 8). This is an excellent example of the way in which memories can be altered in the public sphere; an instance where the past is collectively recalled - or omitted - during the construction of the history of a given civic community (Patronos 2002: p. 149). The true potential of using the past for multiple possible benefits can be understood when we consider that it was within reach and at the discretion of any polis or other political entity, regardless its power or size. In effect, it was a very prominent tool in the arsenal of relatively smaller poleis, as bigger or more powerful ones possessed other more direct means, as well as a bigger arsenal towards such ends.

To conclude, I have argued that the arbitrations of territorial disputes positively demonstrate the many opportunities they offered for any polis and that political use of the past was implicated in almost every aspect of reality - as it is the case today. Any political authority could appeal to arbitration, and a positive verdict was lying as far as the presentation of 'informed' historical evidence and a strong argument. The pragmatic and ideological benefits of such opportunities are seemingly vast. In any case and irrespective of the outcome, the memory of the history of the polis could be altered - the public posting or absence of it could reshape the identity of the community, its memories, and the ways all these were perceived internally and externally. As in many other instances, the past - mythic, distant, or recent - proved to be a crucial source of power and an effective political tool. Constructed, believed or real, it was ever present and was both an effective resource and a guide for political practice.

\section{Bibliography}

Ager, S. L. (1996). Interstate Arbitrations in the Greek World, 337-90 B.C. Berkeley: University of California Press.

Assmann, J. (2011). Cultural Memory and Early Civilization: Writing, Remembrance, and Political Imagination. Cambridge: Cambridge University Press. 
Bagnall, R. S., \& Derow, P. S. (Eds.). (2004). The Hellenistic Period: Historical Sources in Translation. Oxford: Blackwell.

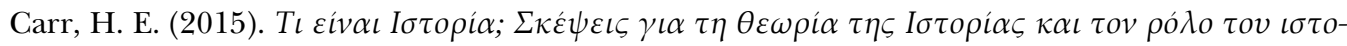

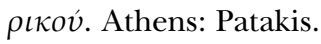

Chaniotis, A. (2004). Justifying Territorial Claims in Classical and Hellenistic Greece: The Beginning of International Law. In E. M. Harris, \& J. S. Rubenstein (Eds.), The Law and the Courts in Ancient Greece (pp. 185-213). London: Bloomsbury.

Clarke, K. (2008). Making Time for the Past: Local History and the Polis. Oxford: Oxford University Press.

Curty, O. (1989). L'historiographie hellénistique et l'inscription no. 37 des Inschriften von Priene. In M. Piérart, \& O. Curty (Eds.), Historia Testis: mélanges d'épigraphie, d'histoire ancienne et de philologie offerts à Tadeusz Zawadzki (pp. 21-35). Fribourg: Editions Universitaires Fribourg.

Fentress, J., \& Wickham, C. (1992). Social Memory. Oxford: Blackwell.

Flower, M. (2002). The Invention of Tradition in Classical and Hellenistic Sparta. In A. Powell, \& S. Hodkinson (Eds.), Sparta: Beyond the Mirage (pp. 191-217). Swansea - London: The Classical Press of Wales; Duckworth.

Foxhall, L., Gehrke, H.-J., \& Luraghi, N. (Eds.). (2010). Intentional History: Spinning Time in Ancient Greece. Stuttgart: Franz Steiner Verlag.

Gehrke, H.-J. (2001). Myth, History, and Collective Identity: Uses of the Past in Ancient Greece and Beyond. In N. Luraghi (Ed.), The Historian's Craft in the Age of Herodotus (pp. 286-313). Oxford: Oxford University Press.

Gehrke, H.-J. (2014). Geschichte als Element antiker Kultur: Die Griechen und ihre Geschichte(n). Berlin: De Gruyter.

Gibson, B. (2014). The Representation of Greek Diplomacy in Tacitus. In J. M. Madsen, \& R. Rees (Eds.), Roman Rule in Greek and Latin Writing: Double Vision (pp. 124-143). Leiden: Brill.

Giovannini, A. (2007). Les relations entre états dans la Grèce antique: du temps d'Homère à l'intervention romaine (ca. 700-200 av. J.-C.). Stuttgart: Franz Steiner Verlag.

Higbie, C. (1997). The Bone of a Hero, the Ashes of a Politician: Athens, Salamis, and the Usable Past. Classical Antiquity, 16(2), 278-307.

Hobsbawm, E., \& Ranger, T. (Eds.). (2000). The Invention of Tradition. Cambridge: Cambridge University Press.

Kinneavy, J. L. (2002). Kairos in Classical and Modern Rhetorical Theory. In P. Sipiora, \& J. S. Baumlin (Eds.), Rhetoric and Kairos: Essays in History, Theory, and Praxis (pp. 58-76). New York: State University of New York Press.

Kinneavy, J. L., \& Eskin, C. R. (2000). Kairos in Aristotle's Rhetoric. Written Communication, 17(3), 432-444.

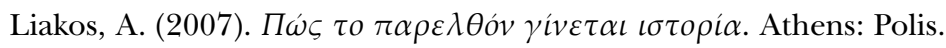

Lund, H. S. (1992). Lysimachus: A Study in Early Hellenistic Kingship. London - New York: Routledge.

Luraghi, N. (2002). Becoming Messenian. The Journal of Hellenic Studies, 122, 45-69.

Luraghi, N. (2008). The Ancient Messenians: Constructions of Ethnicity and Memory. Cambridge: Cambridge University Press.

Luraghi, N. (2009). Messenian Ethnicity and the Free Messenians. In P. Funke, \& N. Luraghi, 
(Eds.), The Politics of Ethnicity and the Crisis of the Peloponnesian League. Washington: Harvard University Press.

Mac Sweeney, N. (2013). Foundation Myths and Politics in Ancient Ionia. Cambridge: Cambridge University Press.

Mac Sweeney, N. (Ed.). (2015). Foundation Myths in Ancient Societies: Dialogues and Discourses. Philadelphia: University of Pennsylvania Press.

Magnetto, A. (1997). Gli arbitrati interstatali greci. Volume 2: dal 337 al 196 A.C. Pisa: Scuola Normale Superiore.

Magnetto, A. (2008). L'arbitrato di Rodi fra Samo e Priene. Edizione critica, commento e indici. Pisa: Edizioni della Normale.

Magnetto, A. (2009). La querelle territoriale entre Samos et Priène: propositions pour un débat. Topoi, 16(1), 7-17.

Magnetto, A. (2016). Interstate Arbitration and Foreign Judges. In E. M. Harris, \& M. Canevaro (Eds.), The Oxford Handbook of Ancient Greek Law. Oxford: Oxford University Press.

Patronos, S. (2002). Public Architecture and Civic Identity in Classical and Hellenistic Ionia. Diss., University of Oxford.

Patterson, L. E. (2010). Kinship Myth in Ancient Greece, Austin: University of Texas Press.

Piccirilli, L. (1973). Gli arbitrati interstatali greci. Volume 1: dalle origini al 338 A.C. Pisa: Edizioni Marlin.

Roebuck, D. (2001). Ancient Greek Arbitration. Oxford: Holo Books.

Sherwin-White, S. M. (1985). The Edict of Alexander to Priene, a Reappraisal. The Journal of Hellenic Studies, 105, 69-89.

Shipley, D. G. J. (1987). A History of Samos, 800-188 BC. Oxford: Clarendon Press.

Shipley, D. G. J. (2013). Afterword: Hellenistic Oratory in Context. In C. Kremmydas, \& K. Tempest (Eds.), Hellenistic Oratory: Change and Continuity (pp. 361-368). Oxford: Oxford University Press.

Stafford, E. (2012). Herakles. Abingdon: Routledge.

Tod, M. N. (1913). International Arbitration Amongst the Greeks. Oxford: Clarendon Press.

Walsh, W. H. (1960). Philosophy of History: An Introduction. New York: Harper Torchbooks.

Welles, B. C. (1934). Royal Correspondence in the Hellenistic Period: A Study in Greek Epigraphy. New Haven: Yale University Press.

Manolis E. Pagkalos / mp482@le.ac.uk

School of Archaeology and Ancient History

University of Leicester

University Road, Leicester LE1 7RH, Great Britain 
